\title{
O NÓ DA REFORMA TRIBUTÁRIA NO BRASIL (1995-2008)
}

\section{Murilo de Oliveira Junqueira}

Universidade de São Paulo (USP), São Paulo - SP, Brasil. E-mail: murilo.junqueira@usp.br

DOI: http//dx.doi.org/10.17666/308993-113/2015

\section{Introdução}

O sistema tributário é um dos nós do desenvolvimento econômico e social do Brasil. A necessidade de uma reforma tributária deixou de ser apenas uma opinião de especialistas, tornou-se unanimidade nacional (Afonso, 2010). Desde 1988, todos os presidentes eleitos declararam querer uma reforma tributária, sendo que dois enviaram propostas de reforma ao Congresso. Contudo, todas estas tentativas de reforma falharam.

O governo Fernando Henrique Cardoso enviou ao congresso uma proposta de reforma tributária (Proposta de Emenda Constitucional [PEC] n. 175 de 1995) $)^{1}$ que chegou a ser aprovada na comissão especial de mérito, mas nunca foi votada no plenário da Câmara dos Deputados. A reforma

Artigo recebido em 03/07/2014

Aprovado em 22/05/2015 foi abandonada pelo Executivo e pelas lideranças políticas, sendo finalmente arquivada no início de 2003. O governo Luiz Inácio Lula da Silva enviou outra proposta de reforma tributária ao Congresso: a PEC 41/2003. Ela foi aprovada pela Câmara dos Deputados em setembro de 2003, mas não foi aprovada pelo Senado. ${ }^{2}$ Em 2008, o governo Lula enviou outra proposta ao parlamento: a PEC 233/2008, apensada à PEC 31/2007. Ela foi aprovada pela comissão especial em novembro do mesmo ano, mas jamais chegou a entrar na pauta do plenário da Câmara dos Deputados.

Em resumo, as propostas de reforma tributária parecem sofrer de crônica paralisia decisória. Quais seriam os motivos desse impasse? Por que o consenso sobre a necessidade de uma solução para o problema tributário não é suficiente para a aprovação da reforma? Será que a incapacidade de aprovar a reforma tributária demonstra uma falha de nosso sistema político? 
Argumento neste artigo que as respostas para essas questões não estão na estrutura política brasileira, mas na estratégia adotada pelos sucessivos governos. A ampla insatisfação com o sistema tributário induz o governo a propor reformas amplas, que alteram muitos aspectos da intrincada estrutura tributária. Essas propostas geram conflitos multidimensionais, isto é, clivagens políticas simultâneas, impedindo a formação de uma coalizão de vitória mínima. A multidimensionalidade é uma característica crônica das propostas de reforma tributária. Esse é o segredo de seu fracasso.

Este artigo fornece uma metodologia para a contagem e a análise de clivagens políticas presentes em uma reforma. Com essa abordagem conseguimos elucidar as razões da incapacidade dos governos aprovarem uma reforma tributária, ao passo que outras propostas complexas e difíceis foram aprovadas. Para mostrar em que a reforma tributária se diferencia de outras reformas constitucionais, selecionamos dois grupos de controle. Um é formado pelas reformas do Judiciário e administrativa, que compartilhavam muitas das características da reforma tributária, como grande relevância social, alta complexidade técnica e intensa disputa política. Contudo, elas não apresentavam o problema da multidimensionalidade e foram aprovadas. O outro grupo é formado por emendas constitucionais (ECs) que, apesar de alterarem os impostos, não foram consideradas "reformas tributárias”. Elas mostraram que é possível mudar os impostos no Brasil, desde que seja de forma incremental.

\section{As reformas tributárias}

Por reforma tributária, entendemos as Propostas de Emenda Constitucional 175/1995, 41/2003 e 233/2008. Essas três PECs formam o conjunto de propostas que será chamado aqui de "reforma tributária". Elas não foram as únicas propostas de alteração do sistema tributário. Então, por que selecionar somente essas três propostas e não qualquer outro conjunto? Três razões justificam esta escolha. Em primeiro lugar, as três propostas envolvem reformas constitucionais.
Como o sistema tributário brasileiro é altamente constitucionalizado, são necessárias emendas constitucionais para fazer mudanças nos aspectos principais dos tributos. Em segundo lugar, as propostas foram apresentadas pelo presidente. Dadas as regras do presidencialismo brasileiro, propostas do Poder Executivo têm muito mais chances de serem aprovadas. As propostas de reforma tributária de iniciativa parlamentar jamais chegaram a ter relevância política. Por fim e mais importante, somente essas três propostas foram consideradas pelos atores políticos relevantes - mídia, Poder Executivo e parlamentares - como propostas de reforma tributária. Então, estamos usando a definição de reforma tributária dos próprios atores políticos.

\section{A questão tributária no Brasil}

O Brasil já teve um dos sistemas tributários mais modernos do mundo. A reforma feita pelo regime militar em 1965 e 1967 foi uma das primeiras do mundo a introduzir um imposto sobre valor agregado, modelo que viria a se tornar dominante nos países desenvolvidos (Varsano, 1997). Porém, após a redemocratização, a necessidade de obter aumentos imediatos de arrecadação, além da trajetória desorganizada dos tributos sobre o consumo induzida pela Constituição de 1988, resultou em sérias perdas de qualidade do nosso sistema tributário. Entre os problemas do sistema tributário, podemos destacar:

a. Excesso de burocracia: segundo o grupo Doing Business (2011), do Banco Mundial, em nenhum país as empresas perdem tanto tempo com a burocracia tributária como no Brasil. Um empreendimento padrão gasta cerca de 2600 horas por ano com o preenchimento de formulários, registros em livros contábeis, assessoria, filas etc. No Chile gasta-se 316 horas para a mesma finalidade. Na Bolívia, o segundo pior país, gastam-se 1080 horas. Isto acontece porque a legislação tributária é extremamente complexa. Apenas o ICMS possui 27 legislaçôes diferentes, uma para cada unidade 
federativa. Uma empresa que atue no mercado nacional precisa se submeter a todas essas legislações, que foram criadas de forma independente e desarmônica. Tal emaranhado burocrático incentiva a informalidade, a sonegação, aumenta os custos de transação e o "peso morto" dos impostos, reduzindo a eficiência geral da economia.

b. Regressividade: o peso elevado dos tributos indiretos faz com que a carga tributária seja altamente regressiva (Pintos-Payeras, 2010; Silveira et al., 2013; Zockun et al., 2007). Assim, o sistema tributário contribui decisivamente para a gritante disparidade de renda do país.

c. Tributação sobre setores errados: a maioria dos países não tributa (ou tributa pouco) produtos que geram elevado bem-estar, como alimentos e remédios. Igualmente, os investimentos e as exportações costumam ter tratamento privilegiado, pois contribuem para o desenvolvimento econômico do país. Já no Brasil, esses setores são taxados, pois a autoridade para taxar a produção pertence parcialmente aos estados (através do ICMS), provocando um problema de "tragédia dos recursos comuns" (Baratto, 2006). Os alimentos são tributados porque os estados agrícolas sabem que uma parte do imposto será pago pelos consumidores de outros estados. Logo, os estados podem taxar os contribuintes de fora de sua jurisdição. Porém, como todos pensam assim, todos são prejudicados. Remédios e bens de capital apresentam problema parecido. Eles são taxados porque a produção desses bens é concentrada em estados industrializados, que resistem a desonerações nesse setor. As exportaçôes constituem um caso mais complexo. Legalmente, elas deveriam ser isentas, mas isto não acontece devido a um imbróglio no sistema tributário. Devido à desarmonia entre as regras do comércio interno e do comércio internacional, os estados perdem arrecadação quando empresas sediadas em seu território exportam, o que os desestimula a pagar os devidos créditos tributários aos exportadores e mesmo a apoiar a exportação. ${ }^{3}$ d. Desoneração sobre setores errados (guerra fiscal): os estados usam reduçóes tributárias para atrair investimentos, o que se convencionou chamar de "guerra fiscal". A maior parte da literatura econômica vê esse fenômeno negativamente, pois ele significaria uma desoneração tributária "errada" (Arbix, 2002; Dulci, 2002; Nascimento, 2008; Oliveira, 1999; Prado e Cavalcanti, 2000; Prado, 1999; Varsano, 1997). A guerra fiscal gera distorções econômicas, pois acaba com a "neutralidade" do sistema tributário, induzindo a uma alocação ineficiente dos investimentos no território. Além disso, os empresários não sabem se, ao instalar uma empresa, seus concorrentes receberão algum incentivo fiscal, criando uma concorrência assimétrica. Esta insegurança jurídica é um desestímulo ao investimento, prejudicando o aumento da capacidade produtiva (Appy, 2009).

Como se pode ver, o sistema tributário brasileiro é permeado de problemas. A explanação acima não é exaustiva, mas resume as principais interpretaçôes da literatura econômica. Os problemas mencionados não são considerados de difícil solução do ponto de vista técnico. Na verdade, o sistema brasileiro é muito estranho se comparado a outros países. O Brasil é um dos poucos países do mundo onde o principal imposto sobre o valor agregado (o ICMS) é estadual. Os especialistas em tributação recomendam limites à autonomia dos governos estaduais para tributar, bem como que o imposto sobre consumo seja tributado no destino das mercadorias, e não na origem. Também propõem a unificação (nem que seja de procedimentos) de tributos federais e estaduais sobre o consumo, com a criação de um imposto nacional sobre valor agregado. Isto abriria espaço para a desoneração dos setores "corretos", como investimentos, exportações e produtos de consumo popular. Também diminuiria a burocracia para as empresas e fecharia brechas para a sonegação. A desoneração sobre setores incorretos, via guerra fiscal, seria coibida e substituída por uma política unificada de desenvolvimento regional. Essas propostas eram a principal intenção das três PECs examinadas neste estudo. Mas todas elas falharam. Por quê? 


\section{Explicaçóes sobre o fracasso da reforma tributária}

Há quatro hipóteses para explicar o fracasso das propostas de reforma tributária:

1. Ingovernabilidade do sistema político: nos anos de 1980 e início dos anos 1990, a visão dominante entre os cientistas políticos (Ames, 2003; Lamounier, 1996; Mainwaring, 2001) era de que nosso sistema político tendia à ingovernabilidade, devido, principalmente, ao sistema proporcional com lista aberta e ao presidencialismo. Contudo, as pesquisas empíricas dos anos de 1990 mostraram um resultado totalmente diferente. $\mathrm{O}$ sistema político acabou se mostrando mais ordenado e previsível do que os primeiros críticos esperavam (Figueiredo e Limongi, 1999 e Limongi, 2006). O presidente brasileiro pode ser considerado muito mais forte que o presidente norte-americano, se aproximando dos primeiros-ministros europeus.

2. Poder de veto dos governadores: outro argumento acerca da ingovernabilidade do sistema político ressaltava a influência dos governadores no processo decisório federal (Abrucio, 1998; Stepan, 1999). Nesse argumento, os governadores agiriam como atores de veto das reformas que visassem limitar a autonomia subnacional e impedir a guerra fiscal. Contudo, trabalhos fortemente embasados empiricamente - como Carey e Reinhardt (2003), Arretche (2007) e Cheibub, Figueiredo e Limongi (2009) - não conseguiram encontrar relação entre estado de pertencimento (ou partido do governador) e voto do parlamentar. Os parlamentares não parecem agir segundo bancadas regionais, mas segundo bancadas partidárias. Durante a década de 1990, o Executivo federal conseguiu reverter grande parte da descentralização promovida pela Constituição de 1988, seja com a recentralização de receitas, seja com a imposição de restrições à autoridade subnacional (Arretche, 2013). Não houve poder de veto dos governadores nesses casos. Assim, sistema político e federalismo não podem ser responsáveis pelo fracasso da reforma tributária. Deve haver algum fator intrínseco à reforma que a impede de ser aprovada.
3. Oposição dos capitalistas: argumenta-se que a ação dos empresários poderia ser uma das razōes do fracasso das reformas. Entretanto, essas propostas foram apoiadas pelas grandes associações empresariais, constando inclusive na Agenda Legislativa da Indústria, documento onde a Confederação Nacional das Indústrias (CNI) declara os projetos que apoia (Ferraz, Diniz e Kloeckne, 2008). Na realidade, os governos deram ênfase às reformas destinadas a aumentar a eficiência dos impostos. Propostas redistributivas, como aumentar a progressividade tributária, tiveram papel marginal nas reformas. Todas as reformas estudadas, incluindo as propostas pelo governo Lula, não podem ser consideradas contrárias ao setor empresarial - e mesmo assim fracassaram.

4. Desinteresse do Executivo: Azevedo e Melo (1997) e Melo (2005) alegam que a reforma não foi bem-sucedida por causa da resistência das burocracias fazendárias e orçamentárias. Campos (2002) argumenta de forma parecida para explicar o insucesso da PEC 175/1995, ao afirmar que a instabilidade econômica no final do mandato de Fernando Henrique Cardoso fez com que as prioridades mudassem das reformas estruturais para o ajuste fiscal de curto prazo. Entretanto, deve-se considerar que as burocracias fazendárias e orçamentárias possuem limitado poder sobre o parlamento. Uma vez que a proposta chega ao Congresso, o único poder que as altas burocracias têm é o de informar os parlamentares com seu conhecimento técnico sobre tributação. Não podemos negar que as dificuldades técnicas das propostas dificultaram seu sucesso, mas isto é diferente de reconhecer nas burocracias um ator com poder de veto. Em segundo lugar, devemos nos perguntar por que o Executivo, supostamente desinteressado na reforma, enviou três grandes propostas ao Legislativo. A estratégia do governo FHC, de ter abandonado sua proposta durante oito anos, não pode ser estendida ao governo Lula. Ao menos no caso da PEC 41/2003, o governo mostrou grande interesse em implementá-la, fazendo com que fosse aprovada nas comissões da Câmara e no plenário sob tempos mínimos de tramitação. Para isso, utilizou todos os recur- 
sos à disposição: trocou parlamentares das comissões (inclusive das comissões permanentes), diminuiu o número de medidas provisórias nas proximidades das votações e liberou um grande número de emendas parlamentares nos dias próximos das votações. Mesmo a decisão de FHC não pode ser creditada a um suposto desinteresse pela proposta, mas a uma mudança de estratégia. O Executivo, vendo as dificuldades por que passava a PEC 175/1995, resolveu selecionar alguns pontos chaves para serem modificados por lei complementar e por pequenas reformas constitucionais. Isso resultou, entre outras coisas, na aprovação da reformulação do Imposto de Renda Pessoa Jurídica e na lei Kandir em 1995 e 1996, respectivamente. A Lei Kandir (LC 87/1996) continha muitos pontos semelhantes à PEC 175/1995, como a desoneração das exportações de bens primários e do ativo fixo das empresas.

Assim, o desinteresse do Executivo não foi a causa do fracasso da reforma tributária, mas o contrário: o fracasso da reforma provocou o desinteresse do Executivo. O governo Fernando Henrique Cardoso foi muito ativo no campo tributário e fiscal, mas concentrou sua ação nas leis infraconstitucionais e em pequenas reformas constitucionais. $\mathrm{O}$ primeiro governo Lula foi o único que resolveu jogar todas as fichas em uma grande reforma constitucional, resultando em derrota para o presidente. O segundo governo Lula não foi tão ousado, evitando colocar a PEC 233/2008 no plenário antes de um firme consenso com a base aliada - consenso esse que nunca houve.

Portanto, se a estrutura política brasileira fortalece o poder do presidente, se a influência dos governadores sobre os parlamentares é reduzida, se os empresários estavam apoiando inicialmente a proposta, e se o argumento de que os governos não tinham real interesse na proposta não pode ser aceito, qual seria, então, o motivo para a crônica incapacidade de se aprovar uma reforma tributária no Brasil? A meu ver, a reforma tributária, tal como apresentada pelos sucessivos governos, apresentava muitas dimensões de intervenção, impedindo a formação da maioria necessária para aprovação de uma reforma constitucional. Chamarei esta hipótese de "argumento da multidimensionalidade".

\section{O conceito de multidimensionalidade}

Apresento a seguir o argumento da multidimensionalidade graficamente, seguindo o instrumental teórico da "teoria espacial do voto" (Krehbiel, 1988; Mckelvey, 1976, 1979; Ordeshook, 1997; Shepsle, 1979, 1986; Tsebelis, 1997). Por "dimensão" entendemos um tema ou uma questão política (issue) que pode ter valor maior ou menor. A centralização ou a descentralização das competências federativas, uma carga tributária maior ou menor, flexibilidade versus rigidez administrativa, maior controle estatal versus maior liberdade de mercado são exemplos de dimensões. A referência geométrica (dimensão) não é gratuita, pois é possível elaborar um modelo simplificado onde uma questão ou proposta política é representada por um eixo euclidiano unidimensional (Figura 1).

As diferentes opiniōes sobre o tamanho da carga tributária estão representadas no eixo. Quanto mais à direita, maior a preferência por alta carga tributária; quanto mais à esquerda, menor a tolerância à alta carga tributária. Nesse eixo, distribuem-se três partidos. É necessário o acordo da maioria para mudar o status quo. Quanto maior a distância entre os pontos ideais de dois partidos, menor a chance de eles fazerem um acordo. No exemplo da Figura 1, os partidos 1 e 2 podem propor uma mudança do status quo para

Figura 1

Baixa Carga

Tributária

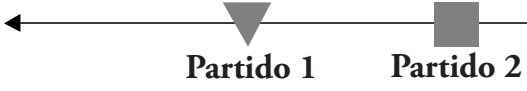

Fonte: Elaboração própria.
Alta Carga

Tributária

\section{Clivagem Unidimensional (1)}

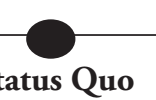

Partido 3 


\section{Figura 2}

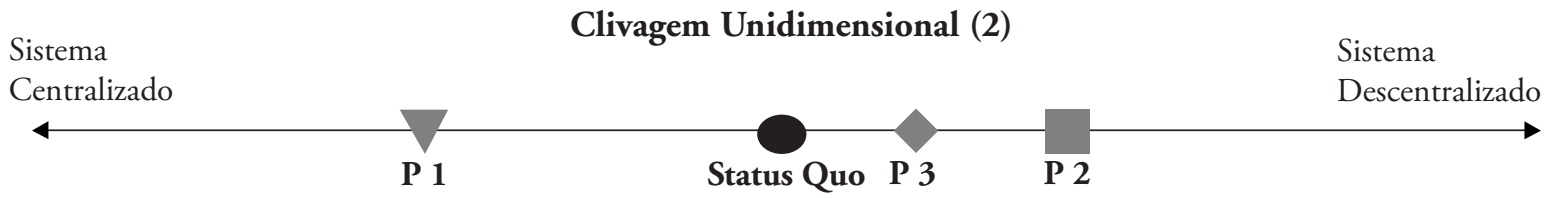

Figura 3

Clivagem Bidimensional (1 e 2)

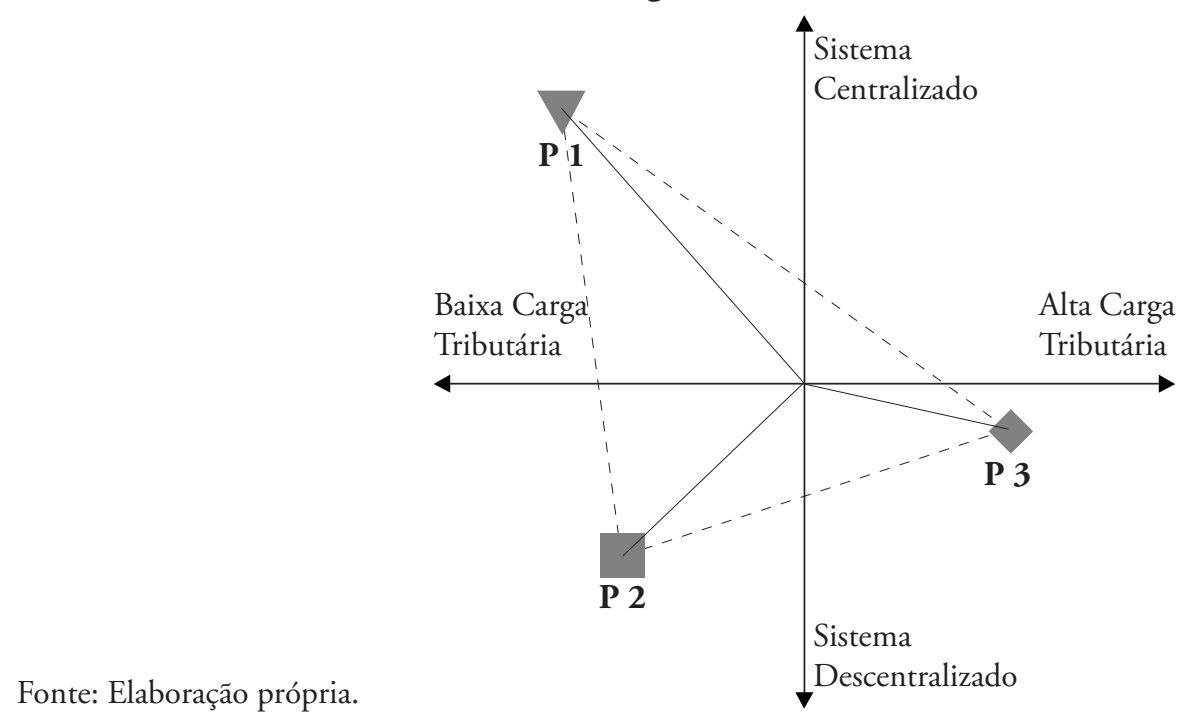

aproximá-lo de suas preferências. As preferências do partido 3 estão mais próximas do status quo; logo, este partido prefere manter o status quo a qualquer mudança proposta pelos demais partidos.

Em outra dimensão, como, por exemplo, se o sistema tributário deve ser centralizado ou descentralizado, os mesmos partidos podem ter outra distribuição de preferências, conforme representado na Figura 2. Nesse caso, os partidos 2 e 3 poderão chegar a um acordo e mudar o status quo. O partido 1 , nesta dimensão, preferirá o status quo às mudanças propostas pelos demais partidos.

Porém, se uma proposta de reforma tributária contém as duas dimensões, as chances de haver acordo são severamente reduzidas. Em verdade, se a proposta contiver essas duas dimensões e essa distribuição de preferências, todos os partidos podem preferir o status quo a qualquer reforma. Repare que na Figura 3 as posiçôes ideais de cada partido em cada eixo continuam as mesmas, contudo, agora, as distâncias entre eles aumentaram, fazendo com que todos ficassem mais próximos do status quo dos demais partidos.

Tsebelis (1997) argumenta que o aumento do número de atores com poder de veto em uma disputa política nunca amplia as chances de haver acordo. Mais veto players em uma deliberação somente pode levar à diminuição ou à manutenção das chances de aprovação de uma proposta. O mesmo raciocínio pode ser aplicado às dimensões do conflito. Pode ser que a inclusão de uma nova dimensão não diminua as chances de haver acordo, caso os partidos que já faziam parte da coalizão de apoio à mudança do status quo também concordem com relação a essa nova dimensão. Esse seria o caso se na Figura 2 a distribuição de preferências dos partidos fosse exatamente igual à distribuição na Figura 1. Nesse caso, os partidos 1 e 2 ficariam no mesmo quadrante do gráfico bidimensional da Figura 3 e, portanto, estariam mais próximos uns dos outros do que do status quo. Nessa possibilidade, a inclusão de uma nova dimensão não impe- 
diria o acordo, mas também não o facilitaria. Não é possível que a inclusão de novas dimensōes facilite as mudanças. Novos eixos ou atrapalham ou são neutros.

Em resumo, o aumento no número de dimensões em uma deliberação política tende a diminuir as chances de alteração do status quo, pois os atores que haviam concordado previamente sobre uma dimensão podem estar em desacordo em outra dimensão. É de se esperar que quanto mais dimensões, menor a possibilidade de se formar uma maioria favorável à alteração do status quo.

\section{Metodologia dos estudos de casos}

Este trabalho argumenta que as reformas tributárias apresentadas pelos governos pós-1988 possuíam muitas dimensões, impedindo a formação de uma aliança vitoriosa pró-reforma. Contudo, o problema consiste em determinar o que é muito ou pouco. É preciso procurar algum referencial abstrato ou comparar casos. Neste trabalho, comparo casos. Argumento que a estratégia adotada pelos operadores políticos das reformas tributárias gerou mais clivagens do que as mais amplas reformas aprovadas no período pós-1988: a reforma do Judiciário e a reforma administrativa. Para reforçar o argumento, também analisei todas as alterações que foram feitas entre 1995 e 2010 no título VI, capítulo I, da Constituição Federal, que trata do sistema tributário. Tais alterações caracterizam-se pela incrementalidade e baixo número de dimensōes.

A maior dificuldade para a análise do argumento da multidimensionalidade é mensurar as disputas políticas em torno das reformas. A movimentação política real acerca de uma proposta é uma informação extremamente difícil de se obter. Os lobbies não costumam produzir ou divulgar documentos sobre sua ação política; e mesmo a atuação de um grupo de pressão não pode ser facilmente ligada ao sucesso ou fracasso de determinado projeto legislativo (Mancuso, 2007, pp. 121-137). Para superar esse problema, adotei a seguinte estratégia: a análise do conteúdo das propostas. $\mathrm{O}$ exame dos ganhos e das perdas de cada proposição fornece informaçôes extremamente úteis sobre como os atores deveriam racionalmente se comportar. Essa estratégia apoia-se na tradição iniciada por Theodore J. Lowi (1964), para quem não é a disputa política que determina a política pública (politics make policies), mas, o contrário, as políticas públicas determinam a disputa política (policies make politics). Nessa mesma tradição, James Q. Wilson (1984) afirma que o fator mais importante para determinar o tipo de mobilização política em torno de uma proposta são seus custos e benefícios - ou melhor, seus ganhadores e seus perdedores. Partiremos do pressuposto de que os ganhadores tentarão exercer influência para a aprovação da proposta e os perdedores tentarão impedir sua aprovação. Não apenas o montante dos custos e benefícios importa, mas também sua distribuição. Quanto mais concentrados os custos e benefícios, maior tende a ser seu valor per capita e mais intensa tende a ser a mobilização. Inversamente, quanto mais dispersa for a distribuição dos custos e benefícios, menor tende a ser o montante per capita e menor tende a ser a mobilização gerada.

O Quadro 1 apresenta de forma simplificada as possibilidades de distribuição de ganhos e perdas de uma proposta de reforma.

Quadro 1

Possibilidades de Distribuição de Ganhos e Perdas de uma Reforma

\begin{tabular}{lll}
\cline { 2 - 3 } $\begin{array}{l}\text { Custos } \\
\text { Concentrados }\end{array}$ & \begin{tabular}{l}
\multicolumn{1}{c}{ Benefícios Concentrados } \\
(exemplo: reforma agrária)
\end{tabular} & $\begin{array}{l}\text { Política dos Empreendedores } \\
\text { (exemplo: fim da guerra fiscal) }\end{array}$ \\
\hline Custos Difusos & $\begin{array}{l}\text { Política Clientelista } \\
\text { (exemplo: distribuiçấo de cargos públicos) }\end{array}$ & $\begin{array}{l}\text { Política Majoritária } \\
\text { (exemplo: leis de trânsito) }\end{array}$ \\
\hline
\end{tabular}

Fonte: Wilson (1984). Exemplos de elaboração própria. 
As "políticas clientelistas" costumam ser as mais fáceis de aprovar, pois os ganhadores têm interesse em se mobilizar e os perdedores não. As "políticas dos empreendedores" são o exato oposto. Elas são as mais difíceis de aprovar, uma vez que os adversários da proposta têm mais interesse em se mobilizar do que seus ganhadores. As "políticas dos grupos de interesse" costumam ser extremamente conflitivas, pois tanto os ganhadores quanto os perdedores têm incentivos para se mobilizar. Por fim, as políticas majoritárias possuem custos e benefícios difusos, dando maior margem para atuação autônoma dos agentes públicos.

Em nossa análise, observamos o conteúdo das PECs para examinar sobre quais atores recaem os custos e benefícios concentrados. Neste estudo foram analisadas catorze PECs, sendo cada uma um caso de análise. Três casos se referem ao assunto principal, a reforma tributária (PECs 175/1995, $41 / 2003$ e $233 / 2008$ ). As reformas do Judiciário (EC 45/2004) e administrativas (EC 19/1998) representam mais dois casos. O grupo chamado de "reformas incrementais" ou "pequenas refor- mas tributárias" possui nove casos (ECs 20/1998, 29/2000, 33/2001, 37/2002, 39/2002, 41/2003, 42/2003, 44/2004, 55/2007). ${ }^{4}$

Cada caso possui uma ou mais dimensões, isto é, conjunto de propostas de mudança do status quo dentro de um mesmo tema. Cada dimensão (isto é, tema de reforma) pode ter uma clivagem. Consideramos que existe uma "clivagem" em uma dimensão quando há um ator com perdas concentradas. Quando os custos ou os benefícios em uma destas dimensões não puderam ser delimitados a um ator social específico, consideramos que eles são difusos. Por exemplo, uma proposta que tenha como benefício um orçamento público mais equilibrado ou uma justiça mais eficiente possui benefícios difusos, uma vez que o benefício não é delimitado a um grupo específico e sim espalhado por toda a sociedade. Assim, quando a dimensão da reforma tinha perdedores delimitados (ou seja, não difusos), consideramos essa uma "dimensão com clivagem”. Quanto mais dimensôes com clivagem tiver um caso, maior será o problema da multidimensionalidade.

Quadro 2

Dimensóes das Reformas Tributárias

\begin{tabular}{lll}
\hline Dimensóes & Ganhadores & Perdedores \\
\hline $\begin{array}{l}\text { Unificaçáo do ICMS } \\
\text { (os estados perdem a autonomia para regular o }\end{array}$ & Difuso & Estados, contribuintes \\
ICMS, mas continuam arrecadando o imposto) & & \\
\hline
\end{tabular}

Fim dos Benefícios estaduais para as empresas Difuso

Estados pouco industrializados e (guerra fiscal)

Instituiçáo do Princípio do Destino

(a arrecadaçáo passa do estado produtor para o

estado consumidor das mercadorias)
AC, AP, DF, MA, PA, PB, PI, RJ, AM, BA, ES, GO, MS, MG, PR, SP $\mathrm{RO}, \mathrm{RN}$

\begin{tabular}{lll}
\hline Aumento da Progressividade dos Impostos & $\begin{array}{l}\text { Classe baixa, esquerda, estados } \\
\text { pobres ou agrícolas }\end{array}$ & Classe alta, direita, empresários \\
\hline $\begin{array}{l}\text { Reformulaçáo das vinculaçóes } \\
\text { constitucionais }\end{array}$ & $\begin{array}{l}\text { União, Ministério da Fazenda e e } \\
\text { Ministério do Planejamento }\end{array}$ & $\begin{array}{l}\text { Setor social, estados, municípios, } \\
\text { BNDES, Ministério do Trabalho }\end{array}$
\end{tabular}

Fonte: Elaboração própria. 


\section{Os nós críticos da reforma tributária}

As três propostas de reforma tributária submetidas ao parlamento brasileiro sob a forma de Propostas de Emenda Constitucional tinham muitos pontos em comum. Suas diferentes dimensōes bem como seu potencial para produzir clivagens estão resumidos no Quadro 2.5

Examinemos cada dimensão das reformas.

\section{A unificação do ICMS}

Esse é o ponto principal e também o mais polêmico das reformas. O ICMS passaria a ter uma legislação única nacional. Os estados continuariam a arrecadar o imposto, mas perderiam a autonomia para legislar sobre ele. Esta medida visa desburocratizar o imposto, evitando que as empresas tenham que obter assessoria tributária em 27 legislações estaduais. Contudo, os estados se opuseram. Não era apenas autonomia que estava em jogo, mas recursos. A proposta de unificação da legislação do ICMS provocou insegurança quanto aos valores futuros das alíquotas do imposto e, consequentemente, quanto à arrecadação futura dos governos estaduais. Um dos exemplos mais citados é o petróleo. As alíquotas da gasolina e do óleo diesel variam de $12 \%$ a $25 \%$. Os combustíveis e lubrificantes derivados de petróleo representam cerca de $20 \%$ da arrecadação total do ICMS. A participação desse setor na arrecadação de ICMS varia de 13\% a $34 \%$ do total estadual. ${ }^{6}$ Se a alíquota dos derivados de petróleo fosse unificada, haveria o risco de perdas concentradas de receitas em alguns estados, caso a alíquota mais alta não prevalecesse. Haveria então um dilema: ou se unificaria as alíquotas "pelo topo", aumentando drasticamente a carga tributária, ou se unificaria as alíquotas nos níveis médios, correndo o risco de penalizar alguns estados.

O mesmo dilema se repete para vários produtos. Cada um deles tem o potencial de gerar uma clivagem política diferente, pois a estrutura produtiva dos estados é muito diferente e o perfil da arrecadação é muito diverso. Para São Paulo, por exemplo, a arrecadação de ICMS de alimentos não é importante $(0,27 \%$ do ICMS em 2002), ao contrário do que ocorre com os estados da região Centro-Oeste $\left(5,11 \%\right.$ em 2002). ${ }^{7}$ Já em relação à pro- dução de remédios e bens de capital se dá o oposto: São Paulo resiste à diminuição da tributação de tais produtos, pois isso lhe traria perdas concentradas.

Como se não bastasse isso, existe outro problema: a conta dos ganhadores e dos perdedores não pode ser feita com precisão, pois não se sabe os valores que as alíquotas de cada produto assumirão no futuro. Esse dado não pode ser decidido no momento de votação da emenda constitucional, pois isso não é matéria típica de texto constitucional. As propostas propunham apenas a federalização do imposto. As definições das alíquotas específicas seriam delegadas para outra instância, que poderia ser uma lei federal, como na PEC 175/1995, ou um colegiado de representantes dos governos estaduais (com ratificação do Senado), como nas PECs 41/2003 e 233/2008.

A unificação das alíquotas do ICMS provocou o temor tanto de perda de arrecadação por parte dos estados quanto o temor de aumento da carga tributária por parte dos contribuintes. É importante notar que as questôes relativas à carga tributária são um dos poucos pontos que têm grande visibilidade social na reforma, sendo intensamente exploradas pela mídia e pela oposição. Tanto Cardoso como Lula afirmaram que o objetivo da reforma não era aumentar a arrecadação, mas modernizar e simplificar o sistema tributário. Contudo, eles não conseguiram emitir promessas críveis em relação a esse ponto. As reformas transformavam-se em uma "guerra de comunicação" entre oposição e governo; os primeiros afirmando que o governo pretendia aumentar os tributos e os segundos negando. A unificação do ICMS intercalava, portanto, dois tipos de clivagem: disputas dos estados entre si e disputas dos estados com seus contribuintes. Quanto mais se chegava perto de um consenso em um tema, mais se afastava do acordo em outro. ${ }^{8}$ De fato, a proposta de unificação do ICMS apresentou várias dimensōes internas, e apenas por simplicidade ela foi apresentada em uma única linha no Quadro 2.

\section{Fim da Guerra Fiscal}

Um dos pontos mais polêmicos da reforma é o fim dos benefícios fiscais estaduais do ICMS. Para os especialistas em economia do setor público, o fim da guerra fiscal é um jogo de soma positiva, 
pois beneficia o Estado e a economia. No entanto, para os estados, o fim dos incentivos é um jogo de soma-zero, no qual, São Paulo, o estado mais desenvolvido, ganha e os demais perdem. Assim, o dilema das isençôes fiscais tende a unir os representantes de São Paulo, do governo federal e os especialistas em tributação contra os demais estados.

Os estados não são os únicos interessados na guerra fiscal. As empresas também são parte relevante da discussão. Do ponto de vista empresarial, o fim da guerra fiscal é um jogo de custos concentrados e ganhos difusos. Existe um tipo específico de empresa que se beneficia da guerra fiscal. Em geral, são empresas grandes e mais "móveis”, ou seja, que não dependem de recursos naturais locais ou de proximidade com o mercado consumidor. Elas têm o potencial de barganhar com os estados para conseguir redução de tributos para seus novos investimentos. Obviamente, elas tendem a ser contra o fim dos benefícios fiscais. Elas não estão desorganizadas, existem associações constituídas exclusivamente por indústrias beneficiárias por incentivos fiscais. Sandro Mabel (PR-MT), parlamentar que é empresário e beneficiário de incentivos fiscais, conseguiu ser relator da PEC 233/2008, derrotando o próprio governo, que preferia que a relatoria ficasse com Antônio Palocci (PT-SP). Apesar de Mabel ter acatado a determinação geral de acabar com a guerra fiscal, sua indicação para a relatoria da PEC mostra a força da bancada dos beneficiados por incentivos fiscais (conhecidos como "guerreiros").

Além disso, existe a questão dos benefícios fiscais já concedidos pelos estados. Como muitas empresas só se instalaram em determinadas regiōes devido aos benefícios fiscais, a reversão desses benefícios provocaria uma fuga de capitais, resultando na criação de cidades-fantasma. A minimização desses efeitos requer longos prazos de transição e compensaçôes do governo central. Isso reduz o apelo político da reforma, uma vez que ela se torna cara e com longo prazo de maturação.

\section{Instituição do princípio do destino}

Outro ponto importante da reforma tributária é a instituição do princípio do destino no ICMS,

Quadro 3

Ganhos e Perdas com a Tributação no Destino

\begin{tabular}{ll}
\hline Estados que ganham & AC, AP, DF, MA, PA, PB, PI, RJ, RN, RO, RR \\
\hline Estados que perdem & AM, BA, ES, GO, MS, MG, PR, SP \\
\hline Estados com impacto neutros* & AL, CE, MT, PE, RS, SC \\
\hline
\end{tabular}

* Ganho ou perda menor que $10 \%$ da receita do ICMS.

Fonte: Baratto (2006).

Quadro 4

Bancadas dos Estados que Perdem e dos Estados que Ganham com a Tributação no Destino

\begin{tabular}{lll}
\hline Total de Deputados dos estados que ganham & 151 & $29,4 \%$ \\
\hline Total de senadores dos estados que ganham & 33 & $40,7 \%$ \\
\hline Total de deputados dos estados que perdem & 235 & $45,8 \%$ \\
\hline Total de senadores dos estados que ganham & 24 & $29,6 \%$ \\
\hline Total de deputados ganham ou “neutro" & 278 & $54,2 \%$ \\
\hline Total de senadores que ganham ou "neutro" & 57 & $70,4 \%$ \\
\hline
\end{tabular}

Fonte: Barato (2006) e Junqueira (2010). 
ou seja, a arrecadação deixaria de pertencer ao estado de origem da mercadoria e passaria ao estado consumidor.

Essa proposta tende a favorecer os estados deficitários na balança comercial interestadual e prejudicar os estados "exportadores líquidos" na federação. Baratto (2006) calculou quem ganha e quem perde em uma transição do ICMS para o destino. Os Quadros 3 e 4 mostram a distribuição dos ganhos e perdas nesta projeção.

Como se pode perceber, nem os estados cujos representantes deveriam se posicionar contra a reforma nem aqueles cujos representantes deveriam se posicionar a favor da reforma atingem o patamar de $50 \%$ em nenhuma das casas legislativas. Mesmo em um cenário otimista, em que os estados "neutros" se posicionassem a favor da mudança, a maioria seria precária, não atingindo o quorum mínimo de três quintos na Câmara dos Deputados, necessário para aprovar uma proposta de emenda constitucional.

Ainda que Carey e Reinhardt (2003) e Arretche (2007) tenham demonstrado que não há relação entre o estado de pertencimento e o voto dos parlamentares, não é plausível esperar que um parlamentar vote favoravelmente a uma perda grave da arrecadação de seu estado. Aliás, deve-se ressaltar que uma perda brusca de receita dos governos estaduais também não é de interesse do governo federal.

Portanto, a inconveniência de impor perdas severas e abruptas a determinados estados força os negociadores a formular mecanismos de compensação e a deslocar no tempo os efeitos das propostas. $\mathrm{Na}$ PEC 233, por exemplo, o último acordo discutido determinava que a transição para o destino iria demorar mais de dez anos. Como consequência, o presidente e os governadores não poderiam usufruir dos benefícios da reforma, apesar de terem que arcar com seus custos.

\section{Aumento da progressividade dos impostos}

Além de alterar as regras do ICMS, as propostas também propunham tornar o sistema tributário mais redistributivo. As três PECs propunham a redução dos impostos para alimentos. Essa me- dida foi muito defendida pela esquerda, mas sofreu oposição dos estados pobres e agrícolas. Os estadosagrícolas se opuseram porque a tributação é na origem e, portanto, uma desoneração lhes traria perdas concentradas. Os estados pobres se opuseram porque não possuem muitas bases tributáveis e, por isso, oneram o consumo da classe baixa. Conforme mostra Vianna, Silveira e Tomich (2000), os estados mais pobres possuem uma tributação mais regressiva do que os estados mais ricos.

A PEC 175/1995 instituía a progressividade do Imposto Predial e Territorial Urbano (IPTU). A PEC 41/2003 determinava que a Contribuição Social sobre Lucro Líquido (CSLL) do setor financeiro não poderia ser menor do que a de nenhum outro setor. Ela também permitia a cobrança de IPVA de barcos e aeronaves. Tanto a proposta de 1995 como a de 2003 instituíam a progressividade do Imposto de Herança (ITCM) e do Imposto de Transmissão de Bens Intervivos (ITBI) e facilitavam a aprovação do Imposto sobre Grandes Fortunas (IGF), facultando sua regulamentação por lei ordinária e não por lei complementar.

$\mathrm{O}$ aumento da progressividade acrescenta uma nova dimensão à reforma, envolvendo preferências ideológica entre a esquerda e a direita. Nesse caso, os conflitos não seguem apenas critérios regionais, mas também partidários.

\section{Reformulação das vinculações constitucionais}

A Constituição determina uma série de vinculações aos impostos federais e estaduais. Por exemplo, $45 \%$ da arrecadação do Imposto de Renda e do Imposto sobre Produtos Industrializados (IPI) deve ser distribuído aos estados e municípios através do Fundo de Participação dos Estados e do Distrito Federal (FPE) e Fundo de Participação dos Municípios (FPM). As contribuições sociais são vinculadas aos gastos com saúde, assistência social e previdência. Existe também uma contribuição que é destinada à educação básica: o salário educação, que é cobrado sobre a folha de pagamento das empresas. O PIS/Pasep também têm vinculações destinadas a programas do Ministério do Trabalho (seguro desemprego, Fundo de Amparo ao Trabalhador, abono salarial) e ao BNDES. 
Nessa dimensão, os atores que têm benefícios concentrados com os impostos vinculados criam grupos de pressão para aumentar tais tributos e resistem à sua desoneração. Desse modo, a autoridade fazendária perde liberdade para fazer política tributária. Diante desses fatos, as reformas previam alterações no sistema de vinculações, seja tornando os vínculos relativos ao orçamento e não mais a um imposto específico (como na PEC 233/2008), seja ampliando a base das vinculações (como na PEC 175/1995).

Porém, esta dimensão das reformas encontrou uma resistência que era ao mesmo tempo pragmática e ideológica. Os setores ligados à saúde, à assistência social e aos sindicatos de trabalhadores criticaram a PEC 233/2008 como um ataque ao orçamento da seguridade social. Eles não queriam ver desmontado o modelo de seguridade social criado em 1988. Em 15 de abril de 2009, cerca de sessenta entidades sociais entregaram ao presidente da Câmara dos Deputados, Michel Temer (PMDB-SP), um documento intitulado "Manifesto em Defesa dos Direitos Sociais Básicos sob Ameaça na Reforma Tributária" (Organizaçōes Sociais, 2009). Entre essas entidades estavam a Conferência Nacional de Bispos no Brasil (CNBB), o Movimento dos Trabalhadores Rurais Sem Terra (MST), a Associação Brasileira de Organizações Não Governamentais (Abong), o Conselho Nacional de Saúde, o Conselho Federal de Serviço Social, o Conselho Nacional dos Secretários de Saúde, o Conselho Nacional de Secretários de Educação e seis centrais sindicais (incluindo as duas maiores, CUT e Força Sindical). Para esses atores, o sistema de tributos vinculados é garantia de permanência dos recursos sociais. Portanto, reformular o sistema de vinculações federais criou mais uma clivagem na reforma, gerando temor de que haveria cortes de recursos para as áreas sociais. Contudo, vale dizer: não há nenhuma evidência de que não seja possível impor perdas desse tipo. Isso foi feito várias vezes, como, por exemplo, na aprovação do Fundo Social de Emergência, em 1994, que desvinculou 20\% dos recursos do orçamento da seguridade social. Tal mecanismo, que era para ser temporário, continua em vigor, pois sofreu sucessivas prorrogações. Um dos poucos pontos aprovados na PEC 41/2003 foi sua prorrogação. A "vitória" do setor social na PEC 233/2008 foi resultado de uma aliança com governadores e empresários para formar uma ampla coalizão de veto à reforma.

\section{Grupo de controle 1: reformas do Judiciário e administrativa}

Os dilemas apontados sobre a reforma tributária explicariam seu fracasso? Não seriam eles naturais em qualquer proposta, bastando "vontade política" para superá-los? Realmente, os presidentes brasileiros foram capazes de aprovar grandes reformas desde 1988. Teriam elas também o problema da multidimensionalidade? A seguir mostro que não.

O objetivo desta comparação é testar a hipótese da multidimensionalidade. Selecionamos as reformas mais complexas já aprovadas pelo Congresso Nacional e verificamos se elas também são altamente multidimensionais. Caso a resposta tivesse sido positiva, a hipótese da multidimensionalidade teria sido refutada.

Por que as reformas do Judiciário (EC 45/2004) e a reforma administrativa (EC 19/1998) e não quaisquer outras? Essas reformas foram escolhidas por serem grandes e, portanto, complexas. A reforma do Judiciário foi a maior reforma já feita na Constituição, tanto em número de palavras como em número de artigos alterados. Ela continha 4.646 palavras e alterava 29 artigos. A reforma administrativa foi a terceira maior em número de palavras $(4.240)^{9}$ e a segunda em número de artigos (19). ${ }^{10}$ Como tais propostas foram aprovadas e eram muito complexas, elas poderiam ter sido casos que negassem a hipótese de que a multidimensionalidade possa ser uma característica impeditiva das reformas. Mas, como constataremos, a complexidade dessas reformas era apenas técnica, pois sua capacidade de gerar clivagens políticas era bem mais reduzida.

Comecemos pela reforma do Judiciário. Ela teve longuíssima tramitação, demorou mais de doze anos para ser aprovada (1992-2004). Ao contrário da maioria das grandes reformas, ela foi protagonizada, em uma construção gradual, por iniciativas parlamentares e não pelo poder Executivo. Mas o que propõe? Seu sentido geral é de regular o traba- 


\section{Quadro 5}

Principais Alterações da Reforma do Judiciário ${ }^{11}$

\begin{tabular}{|c|c|c|}
\hline Dimensóes & Ganhadores & Perdedores \\
\hline $\begin{array}{l}\text { Aumento do poder da Cúpula do Judiciário } \\
\text { (criação do Conselho Nacional de Justiça, da } \\
\text { repercussão geral, e da súmula vinculante) }\end{array}$ & $\begin{array}{l}\text { Cúpula do Judiciário, OAB } \\
\text { (que ganha vaga no } \mathrm{CNJ} \text { ) }\end{array}$ & $\begin{array}{l}\text { Tribunais inferiores, escritórios } \\
\text { de advogados especializados em } \\
\text { recursos ao STF }\end{array}$ \\
\hline $\begin{array}{l}\text { Regulaçáo sobre os tribunais inferiores } \\
\text { (mudanças quanto ao processo disciplinar, a } \\
\text { administração dos tribunais, o fortalecimento da } \\
\text { meritocracia, maior controle orçamentário) }\end{array}$ & Difuso & $\begin{array}{l}\text { Juízes de direito não meritórios, } \\
\text { juízes decanos }\end{array}$ \\
\hline $\begin{array}{l}\text { Regulaçáo sobre o Ministério Público } \\
\text { (criação do Conselho Nacional do Ministério Público, } \\
\text { mudanças quanto ao processo disciplinar, maior } \\
\text { controle orçamentário) }\end{array}$ & Cúpula do Ministério Público & $\begin{array}{l}\text { Membros da base do Ministério } \\
\text { Público }\end{array}$ \\
\hline
\end{tabular}

Criação e fortalecimento de direitos fundamentais

Difuso

Difuso

(direito à celeridade judicial, tratados internacionais com força constitucional, adesão ao tribunal penal internacional, direito à privacidade, federalização dos crimes contra os direitos humanos)

\begin{tabular}{|c|c|c|}
\hline Fortalecimento das defensorias públicas & Defensorias públicas & Difuso \\
\hline \multicolumn{2}{|c|}{$\begin{array}{l}\text { Fortalecimento e ampliaçáo do poder normativo daJustiça do Trabalho } \\
\text { Justiça do Trabalho }\end{array}$} & Difuso \\
\hline Justiça itinerante e descentralizada & Difuso & Difuso \\
\hline $\begin{array}{l}\text { Justiça Militar com maior presença de civis } \\
\text { (a Justiça Militar tem consolidada a atribuiçáo de } \\
\text { julgar crimes de militares contra civis, porém juízes } \\
\text { civis são transferidos para a justiça militar) }\end{array}$ & $\begin{array}{l}\text { Juízes de direito civis; } \\
\text { tribunais militares }\end{array}$ & $\begin{array}{l}\text { Juízes militares, corporações } \\
\text { militares }\end{array}$ \\
\hline $\begin{array}{l}\text { Modificaçáo nas atribuiçóes jurisdicionais } \\
\text { (mudanças nas atribuiçốes quanto às atribuiçốes de } \\
\text { julgamentos de leis, sentenças estrangeiras, ADINs e } \\
\text { ADCs) }\end{array}$ & \multicolumn{2}{|c|}{$\begin{array}{l}\text { STF, atores capazes de ADINs e STJ } \\
\text { não ADCs, governador e mesa } \\
\text { da assembleia do Distrito Federal }\end{array}$} \\
\hline
\end{tabular}

Fonte: Elaboração própria.

lho dos juízes de primeira instância e dos tribunais de justiça, seja aumentando o poder dos tribunais superiores (notadamente o Supremo Tribunal Federal), seja criando regras para o funcionamento dos tribunais inferiores. Provavelmente a maior inovação dessa reforma foi a criação de um órgão para fazer o controle administrativo e disciplinar do Judiciário: o Conselho Nacional de Justiça (Sadek, 2010). O Quadro 5 detalha as propostas.

Como se pode observar, há dimensões com custos difusos e benefícios difusos, como o direito à celeridade processual, o direito à privacidade nas açôes judiciais, a adesão ao Tribunal Penal Internacional, criação da justiça itinerante etc. Há dimensões com custos difusos e benefícios concentrados, como o fortalecimento da Justiça do Trabalho e das defensorias públicas etc. Também há dimensões que apresentam custos concentrados, como maior regulamentação sobre os tribunais inferiores, súmula vinculante, fortalecimento do Conselho Nacional de Justiça, do Conselho Nacional do Ministério Público, alterações na Justiça Militar, etc. 
Dessas, apenas o último tipo dá incentivos para algum grupo se mobilizar contra, pois apresenta perdas concentradas evidentes.

Apesar de polêmica (o que evidencia seus doze anos de tramitação), a reforma do Judiciário não apresenta o problema da multidimensionalidade, pois as perdas foram concentradas em dois grupos, a saber, as bases do Judiciário e do Ministério Público. Certamente isso fez com que uma grande parte dos juízes de primeira e segunda instâncias e de membros inferiores do Ministério Público se opusessem à reforma, uma vez que ela tornava mais rígida sua disciplina administrativa e diminuía sua autonomia funcional. Mas eles teriam tido força para vetar a proposta? Ao que tudo indica, não. Os parlamentares deram um voto de desconfiança principalmente aos tribunais inferiores, dado que o Ministério Público foi bem menos afetado. Os tribunais inferiores foram responsabilizados pelas mazelas do Judiciário, pois os legisladores acharam que era melhor criar regulamentos e tutelas sobre eles. A cúpula togada foi investida de poder para cumprir essa tarefa, se tornando um ator com ganhos concentrados.

Analisemos agora a reforma administrativa (EC 19/1998). Esta proposta foi idealizada den-

\section{Quadro 6}

Principais Alteraçóes da Reforma Administrativa ${ }^{12}$

\begin{tabular}{lll}
\hline Dimensóes & Ganhadores & Perdedores \\
\hline $\begin{array}{l}\text { Inclusáo de princípios "gerenciais” na administraçáo } \\
\text { pública } \\
\text { (princípio da eficiência, maiores poderes para os usuários }\end{array}$ & Difusos & Difusos \\
$\begin{array}{l}\text { de serviços públicos; metas e autonomia para os órgãos } \\
\text { da administração indireta; criação de escolas de governo e } \\
\text { consórcios públicos) }\end{array}$ & & \\
\hline
\end{tabular}

Reforma nos vencimentos dos cargos eletivos

(legalidade para os reajustes; possibilidade de aumentar vencimentos da própria legislatura; convocação extraordinária;

substituição dos vencimentos pelos subsídios)
Parlamentares, governadores, prefeitos prefeitos

\section{Empresas Públicas}

Difuso

Empresas públicas

(maior flexibilidade para a criaçáo de empresas públicas;

lei das licitaçôes; mudança dos estatutos das empresas)

\section{Polícia}

(assegura a manutenção das polícias militar e bombeiros do
DF, Polícia Federal
Delegados estaduais

Distrito Federal; redefinição da polícia aeroportuária, ferroviária,

rodoviária; fim da isonomia dos delegados com outras carreiras

análogas)

\section{Ex-territórios}

Ex-territórios

Difuso

(transferências de funcionários federais para ex-territórios)

Servidores Públicos

(reforma dos vencimentos; gestão, concursos públicos e maior controle fiscal)
Governos federais,

Servidores

estaduais e municipais

Fonte: Elaboração própria. 
tro do Ministério da Administração e Reforma do Estado do governo Fernando Henrique Cardoso, sob a gestão do ministro Luiz Carlos Bresser Pereira. O documento intitulado "Plano Diretor da Reforma do Aparelho do Estado" propunha uma ambiciosa reforma, na qual o modelo "burocrático" de administração seria superado pelo modelo "gerencial", que incorporaria a gestão por resultados dentro do Estado (Brasil, Presidência da República, 1995). Porém, a proposta enviada ao Congresso era bem mais sucinta e conservadora. Longe de propor grandes mudanças de paradigma, apresentou uma série relativamente longa de medidas que visavam reduzir o poder do funcionalismo, conforme consta no Quadro 6.

Como na reforma do Judiciário, houve propostas com conteúdo mais geral e ideológico, cuja característica política mais marcante foi não ter nem beneficiários nem perdedores claros. Estas foram as propostas que objetivavam aplicar os princípios da administração pública gerencial ao Estado brasileiro, como eficiência, participação dos usuários na administração de serviços públicos, metas e maior autonomia para órgãos da administração indireta, possibilidade de criação de consórcios públicos etc.

Foram criados instrumentos que fortalecessem o controle do governo sobre as empresas públicas, como a previsão de um novo modelo de estatuto social e a obrigação de submeter as empresas à lei de licitaçóes, o que implicou em custos concentrados nas empresas. A polícia federal teve corrigida algumas distorçōes em suas atribuiçôes, bem como obteve a garantia constitucional de que seria "organizada e mantida" pela União, fortalecendo a corporação. Esta foi uma medida com ganho concentrado e custo difuso. Houve mudanças em relação ao vencimento dos próprios parlamentares. O efeito foi dúbio. Por um lado, medidas que impuseram custos aos parlamentares, como a proibição receber indenização por convocação extraordinária; por outro, removeu-se a regra de que uma legislatura só poderia aumentar os salários da legislatura seguinte e não as próprias remuneraçōes.

Contudo, o alvo principal da reforma foram os servidores públicos. Houve 34 propostas de reforma administrativa que visavam à modificação da contratação, da gestão e da remuneração de funcionários públicos. Dessas, 27 impunham perdas inequívocas a este setor. Podemos citar, por exemplo: a maior facilidade para aprovar a lei de greves do serviço público; a previsão de que todos os benefícios a servidores deveriam ser aprovados por lei (e não por simples resolução administrativa); a instituição de um teto ao funcionalismo igual ao subsídio do ministro do Supremo Tribunal Federal (STF); o fim da isonomia salarial entre funções assemelhadas; o aumento das exceçôes à irredutibilidade dos salários dos funcionários; a maior rigidez das regras de acúmulo de cargo público; a eliminação da obrigatoriedade de regime jurídico único nas instituiçôes de ensino etc. A medida mais polêmica foi a flexibilização da estabilidade do servidor. Pela nova regra, os servidores podem ser demitidos por insuficiência de desempenho (assegurado processo administrativo com contraditório e ampla defesa) e também caso o ente empregador tenha superado os limites com gasto de pessoal determinados pela Lei de Responsabilidade Fiscal. ${ }^{13}$ Estados e municípios fora do limites impostos estariam sujeitos a bloqueios de transferências e empréstimos. Essa medida é mais atentatória aos benefícios dos funcionários do que aos direitos dos governos, pois eles ficam empoderados para resistir a pressões de seu funcionalismo. Com efeito, os governadores de estado foram os grandes apoiadores da reforma (Yoshida, 2006).

A reforma administrativa foi polêmica e teve longa tramitação, cerca de três anos e meio. Contudo, ela não parece ter um problema de multidimensionalidade. Claramente havia uma clivagem principal: servidores versus governos. Podemos entender, assim, por que grande parte do funcionalismo foi contra a proposta, mas o presidente Fernando Henrique conseguiu reunir uma coalizão parlamentar de apoio com os partidos de sua base, vencendo os opositores da reforma.

\section{Grupo de controle 2: reformas incrementais}

Nem todas as propostas de alteração nos impostos sofrem de paralisia decisória. De fato, houve uma série de mudanças constitucionais no sistema tributário desde 1988. Nenhuma dessas medidas teve o título redentor de "reforma tributária", pois eram pontuais e tópicas. Mas, ao contrário das reformas amplas e abrangentes, elas foram aprovadas. 
A PEC 175/1995 autorizava a progressividade do IPTU. Como ela falhou, esta medida naufragou junto. No Brasil, há poucos impostos progressivos sobre a propriedade. Porém, a mesma proposta foi aprovada na Emenda 29/2000. A razão para isso também parece ser simples: a Emenda 29 é bem mais sucinta do que as reformas tributárias. Sua estrutura interna mostra que ela tinha poucas clivagens. Além do IPTU progressivo, ela apenas propunha a ampliação e a vinculação dos recursos para a saúde pública, o que fez com que ela contasse com o apoio entusiasta desse setor.

O governo Fernando Henrique Cardoso também resgatou algumas propostas da PEC 175 na Emenda 33 de 2001. Essa emenda instituía o princípio do destino na Contribuição Social sobre Domínio Econômico (Cide), permitia que os estados e municípios criassem contribuições previdenciárias sobre seus funcionários, eliminava brechas na cobrança de ICMS nos importados, instituía o imposto monofásico sobre os combustíveis e criava a Cide-Combustíveis. A Cide-Combustíveis acabou se tornando um imposto bem avaliado e alguns deputados criticaram a proposta de seu fim na comissão especial da PEC 233/2008, argumentando que sua criação havia instituído uma fonte segura e estável para os projetos de infraestrutura em transportes. De todas as propostas da EC 33, as únicas que produziam custos concentrados eram a criação da Cide-Combustíveis, que onerava o setor de transportes, e a contribuição previdenciária dos funcionários públicos. Todas as demais possuíam perdedores difusos.

A história se repetiu na Emenda 37 de 2002, que tinha como propostas: (a) regulação dos pagamentos dos precatórios, (b) prorrogação da CPMF até 31 de dezembro de 2004; e (c) impedir a guerra fiscal do ISS através de leis nacionais e uma alíquota mínima. Essa última proposta também foi extraída da PEC 175 de 1995. Os municípios tiveram nova vitória com a Emenda 39 de 2002, que altera um artigo da Constituição e permite aos municípios estabelecer taxas sobre a energia elétrica para custear o serviço de iluminação pública.

A reforma da previdência do governo Lula, Emenda 41 de 2003, também alterou um parágrafo do capítulo tributário da Constituição, modifican- do a contribuição previdenciária dos funcionários públicos. Essa reforma guarda semelhanças com a reforma administrativa, pois ela opôs governos a servidores públicos, sendo tecnicamente complexa, mas politicamente simples. A reforma da previdência do governo Cardoso, Emenda 20 de 1998, também alterou um inciso do sistema tributário, revogando a isenção de imposto de renda para rendimentos previdenciários de pessoas com 65 anos ou mais. Tal como a Emenda 41, essa reforma se insere em outra disputa, a da previdência pública, atingindo apenas tangencialmente o sistema tributário. Deve-se ressaltar que a reforma da previdência foi realizada em dois tempos. Apesar de Cardoso ter enviado ao Congresso uma reforma ampla em 1995, que previa tanto a reforma da previdência dos servidores públicos como dos trabalhadores do setor privado, a maior parte da reforma do setor público só foi aprovada em 2003, pelo governo Lula. A tática de aprovar primeiro a reforma do setor privado para depois aprovar a reforma do setor público se mostrou eficaz para reduzir a multidimensionalidade das reformas (Silva, 2007).

As Emendas 44 e 55 podem ser caracterizadas como políticas de custo difuso e benefícios concentrados, além de altamente incrementais. Cada uma dessas reformas mudou um artigo da Constituição. A primeira concedeu 29\% da Cide-Combustíveis para os estados e o Distrito Federal e a segunda aumentou em um ponto percentual a destinação do IPI e do Imposto de Renda para o Fundo de Participação dos Municípios.

Por fim, analisamos a Emenda 42, fruto da PEC 41/2003. Após o desmembramento dessa proposta no Senado, que retirou todas as sugestões que reformulavam o ICMS, ela passou a ser integrada predominantemente por medidas que implicavam custos difusos. São exemplos disso: a vinculação dos recursos prioritários para as burocracias tributárias; o princípio da noventena; o Senado passou a ter como atribuição avaliar o Sistema Tributário Nacional; permissão de alíquotas diferenciadas dos tributos federais para fins de política comercial ou industrial; estabelecimento de contribuições sociais sobre os importados e sua isenção sobre os exportados. Prescreveu-se também tratamento privilegiado 
às pequenas empresas, isentou-se de ICMS as rádios e TVs de transmissão gratuitas, abriu-se a possibilidade de os estados vincularem $0,5 \%$ de seu orçamento para cultura e atividades sociais, a Zona Franca de Manaus foi prorrogada por dez anos e determinou-se que a Uniāo deveria enviar projeto de isenção do setor da informática sessenta dias após a aprovação da emenda. As únicas medidas inovadoras e com custos concentrados na reforma referem-se à instituição do princípio do poluidor pagador e à possibilidade de lei federal regular o IPVA, estabelecendo alíquotas mínimas e diferenciadas de acordo com o uso do veículo. Além disso, a reforma constitucionalizou três propostas que, apesar de terem custos concentrados, não eram inovadoras: a prorrogação da DRU, a prorrogação da CPMF e a constitucionalização da isenção tributária na exportação de produtos primários e semielaborados (Lei Kandir). Assim, o setor social, os contribuintes e os estados exportadores de produtos primários não perderam recursos, apesar da consolidação de uma situação que lhes era desfavorável.

Por fim, cabe mencionar que a EC 42 de 2003 inseriu na Constituição outra proposta que já existia em lei: a transformação das contribuições sociais sobre faturamento (PIS/Pasep e Cofins) em contribuições sobre o valor agregado. $\mathrm{O}$ governo Fernando Henrique já havia transformado o PIS/Pasep em tributo sobre valor agregado através da Lei 10.637/02. Tal medida teve um caráter de teste, fazendo com que as burocracias tributárias examinassem os efeitos do novo sistema do imposto. O governo Lula resolveu continuar a proposta e transformou a Cofins (que tem arrecadação muito maior do que o PIS) em imposto sobre valor agregado. A discussão da proposta foi polêmica, pois beneficiava a indústria, mais prejudicaria o setor de serviços. Após alguns meses de discussão, o governo concordou em manter alguns setores dos serviços no sistema antigo, removendo resistências à proposta. No final de 2003, a Lei $10.8333 / 03$ foi aprovada e logo em seguida a Emenda 42 a consolidou na Constituição. Ou seja, as reformas incrementais anteriores, via lei ordinária, abriram caminho para a mudança constitucional.

\section{Conclusão}

Nossa explicação para o fracasso das propostas de reforma tributária amplas incorpora argumentos apresentados por explicações anteriores, mas acrescenta que a multidimensionalidade de uma proposta de reforma pode ser um impeditivo relevante para a mudança do status quo. De fato, a fragmentação e a indisciplina partidárias podem ter facilitado a ação de lobbies para vetar a reforma. Contudo, apenas a fragmentação partidária não explica o fracasso da reforma tributária, pois reformas amplas, mas com poucas clivagens, como as reformas administrativa e do Judiciário, foram aprovadas. Ainda que as disputas federativas tenham afetado a reforma tributária, os governos subnacionais têm limitado poder de veto no Brasil. Ainda que a atuação de grupos empresariais, especialmente os empresários beneficiários da guerra fiscal, tenha sido visível na tramitação das reformas tributárias, é de se estranhar que um pequeno grupo de empresários conseguisse vetar uma proposta com grande potencial para melhorar o ambiente de negócios brasileiro. Por fim, sempre é possível argumentar que o presidente poderia ter se empenhado mais na aprovação da reforma, mas seria necessária uma vontade política excepcional (ou poderes excepcionais) para aprovar propostas de tamanha complexidade política.

Nenhum desses fatores explica isoladamente o fracasso da reforma tributária, tal como formulada nas três reformas apresentadas pelos presidentes Fernando Henrique e Lula. Creio que a multidimensionalidade foi o principal impeditivo para o fracasso das reformas. A grande quantidade de dimensões em cada proposta deu origem a muitas clivagens distintas, o que torna difícil a formação de maiorias parlamentares de sustentação. Muitas dimensões diferentes negociadas ao mesmo tempo também geram incertezas quanto ao impacto agregado das mudanças no status quo, tanto do ponto de vista político como do ponto de vista técnico, aumentando a aversão ao risco dos atores.

Tomemos como exemplo o papel de um parlamentar interessado em defender os interesses do estado de São Paulo. Ele é a favor de manter a tributação do ICMS na origem; logo, é contra a 
reforma. Contudo, defende o fim da guerra fiscal; por isso, se inclina a favor dessa dimensão da reforma. No entanto, ele é contra desonerar os bens de capital, logo, é contra esta dimensão da reforma. Mas, também, quer desonerar os alimentos, o que o coloca a favor desse ponto da proposta. Como o resultado final depende de complexas negociações com parlamentares de todos os estados e partidos, esse parlamentar pode facilmente concluir que é melhor deixar as coisas como estão a arriscar ver seu estado em dificuldades financeiras.

Não acredito, contudo, que o fracasso da reforma se deve ao poder de veto dos governadores, como faz Abrucio (1998). Na verdade, em mudanças mais simples, onde há menos dimensões em disputa, mesmo que envolvam tributos e taxação, é possível aprovar reformas que afetem negativamente os interesses dos governadores. O problema é que existiam mais dimensões nas reformas além daquelas que envolviam os governos estaduais. Imaginemos um parlamentar que tem por bandeira a defesa dos interesses empresariais. Ele é a favor da unificação do ICMS, pois isso simplifica o trabalho tributário das empresas. Portanto, ele é a favor dessa dimensão de uma reforma tributária. Contudo, ele é extremamente avesso a propostas que aumentem a carga tributária. Então, ele não apoia uma proposta em que não estejam presentes mecanismos críveis para garantir melhora na qualidade dos tributos sem o aumento de sua quantidade, mas ele deseja muito a desoneração dos bens de capital e das exportaçōes e começa a pensar seriamente em apoiar uma reforma que contenha tal proposta. Porém, se a reforma aumenta a progressividade dos impostos sobre a propriedade, ele tenderá a ser contra. No final, de seu ponto de vista pode ser prudente não apoiar a reforma e se contentar com o status quo.

As reformas constitucionais relacionadas com o setor tributário que foram aprovadas produziram clivagens políticas mais simples. Logo, as reformas tributárias talvez pudessem ter sido bem-sucedidas caso tivesse tramitado em formato menos complexo. É raro que propostas abrangentes e complexas sejam aprovadas; mais comum é a aprovação de reformas incrementais. ${ }^{14}$ Portanto, não se trata de desejar ou não uma reforma tributária "fatiada". Tal caminho pode não ser uma escolha, mas sim o único caminho para desatar o nó reforma tributária no Brasil.

\section{Notas}

1 Todas as referências a PECs neste texto seguem a numeração da Câmara dos Deputados.

2 O governo desmembrou a proposta para poder garantir a prorrogação da CPMF e da Desvinculação de Receitas da União (DRU), que se transformaram na Emenda 42.

3 Na verdade, há um estímulo para os estados se tornarem importadores, criando uma "barreira tributária às avessas". Para mais detalhes, ver Junqueira (2010, pp. 37-43) e Barato (2006). Em 2012, o Senado conseguiu reduzir a tendência à atrair importações - a chamada "guerra dos portos" - através da Resolução n. 13/2012. Isso reforça o argumento de que apenas as reformas amplas estão paralisadas, não todas.

4 As Emendas 20 e 41 são as reformas da previdência dos governos Cardoso e Lula, respectivamente. Apesar de elas não serem em si reformas pequenas ou incrementais, foram incluídas nesse conjunto porque alteraram apenas um único artigo cada uma no capítulo sobre o sistema tributário nacional. Ou seja, no que diz respeito ao sistema tributário, elas foram reformas incrementais, embora tenham implicado grandes mudanças em outras partes da Constituição.

5 A análise completa das propostas encontra-se disponível em Junqueira (2010).

6 Dados somados de 2002 e 2003. Fonte: Confaz (2003).

7 Dados somados de 2002 e 2003. Fonte: Confaz (2003).

8 Tal visão é corroborada pela análise de Rezende (2009).

9 A segunda maior foi a reforma da previdência do governo FHC, emenda 20 de 1998.

10 Caso as reformas tributárias tivessem sido aprovadas, elas superariam de longe esses números. A PEC 175/1995 possuía 5.505 palavras e alterava 34 artigos; a PEC 41/2003 possuía 4.815 palavras e alterava 32 artigos; a PEC 233/2008 possuía nada menos do que 11.840 palavras e alterava 32 artigos constitucionais. Todos esses casos se referem às últimas versões aprovadas em plenário ou na comissão da Câmara dos Deputados. As emendas constitucionais aprovadas na Constituição possuem em média 597,77 palavras e alteram em média 3,88 artigos (período 1990-2008).

11 Para uma análise completa das propostas, ver Junqueira (2010).

12 A análise completa das propostas encontra-se disponível em Junqueira (2010). 
13 A Lei Complementar 101/2000 (Lei de Responsabilidade Fiscal) foi criada justamente para regulamentar um dispositivo criado pela reforma administrativa, o Artigo 169.

14 Varsano argumenta que mesmo a grande reforma tributária de 1965-1967, feita por um governo ditatorial, foi mais um passo de uma lenta evolução: " $E m$ suma, a reforma da década de 60, a despeito de ter sido extremamente profunda e modernizante, foi apenas um passo a mais - largo, é verdade - na evolução do sistema tributário. A lógica do processo de evolução, que não admite descontinuidades, foi respeitada. Dessa lógica, fundamentada em justificada aversão a riscos, resulta que todo sistema tributário, mesmo os instituidos por reformas profundas, herda caracteristicas de seu antecessor e reflete não só as ideias e condiçôes reinantes na sociedade à época de sua instituição como as que prevaleceram no passado" (1997, p. 21).

\section{BIBLIOGRAFIA}

ABRUCIO, F. (1998), Os barōes da federaçao: os governadores e a redemocratização brasileira. São Paulo, Hucitec.

AFONSO, J. R. (2010), Proposta de sistema tributário. Brasília, Senado Federal.

AMES, B. (2003), Os entraves da democracia no Brasil. Rio de Janeiro, FGV.

APPY, B. (2009), "Necessidade de uma reforma tributária no Brasil”, in R. B. Piscitelli, R. Ellery e T. Costa (eds.), Reforma tributária: a costura de um grande acordo nacional, Sâo Paulo, Atlas, pp. 12-24.

ARBIX, G. (2002), "Políticas do desperdício e assimetria entre público e privado na indústria automobilística". Revista Brasileira de Ciências Sociais, 17 (48): 109-129.

ARRETCHE, M. (2007), "The veto power of sub-national governments in Brazil: political institutions and parliamentary behaviour in the post-1988 period”. Brazilian Political Science Review (on-line), 1 (2): 40-73.

. (2013), "Quando instituições federativas fortalecem o governo central?". Novos Estudos Cebrap, 95: 39-57.

AZEVEDO, S. de \& MELO, M. A. (1997), "A política da reforma tributária: federalismo e mudança constitucional”. Revista Brasileira de Ciências Sociais, 12 (35): 75-99.

BARATTO, G. (2006), "O regime tributário do ICM e ICMS nas transações interestaduais e a competição fiscal entre os estados", in F. Rezende e S. Prado (orgs.), Forúm fiscal dos estados. Relatório 2 - Competição Fiscal. Brasília, Escola de Administração Fazendária - Esaf, pp. 111-170.

BRASIL. Presidência da República. (2005), "Plano diretor da reforma do aparelho do Estado". Brasília. Disponível em http://www.bresserpereira.org.br/Documents/MARE/PlanoDiretor/ planodiretor.pdf, consultado em 2 set. 2015.

CAMPOS, I. W. (2002), Impasse da reforma tributária na era FHC: tecnologia 'versus' elite industrial - o triunfo da arrecadação sobre a produção. São Paulo, tese de doutorado, Departamento de Ciência Política da Universidade de São Paulo.

CAREY, J. M. \& REINHARDT, G. Y. (2003), "Impacto das instituições estaduais na unidade das coalizões parlamentares no Brasil". Dados, 46 (4): 773-804.

CHEIBUB, J. A.; FIGUEIREDO, A. \& LIMONGI, F. (2009), "Partidos políticos e governadores como determinantes do comportamento legislativo na Câmara dos Deputados, 19882006". Dados, 52 (2): 263-299.

CONFAZ. (2003), "Boletim do ICMS e demais impostos estaduais". Disponível em http:// www1.fazenda.gov.br/confaz/boletim/valores. htm, consultado em 21 maio 2015.

DOING BUSINESS, G. (2011), Doing business 2011 making a difference for entrepreneurs. Washington, s. e.

DULCI, O. S. (2002), "Guerra fiscal, desenvolvimento desigual e relações federativas no Brasil”. Revista de Sociologia e Politica, 18: 95-107.

FERRAZ, R. M. M.; DINIZ, G. F. \& KLOECKNE, P. A. (2008), Agenda legislativa da indústria - 2008. Brasília, Confederação Nacional da Indústria - CNI.

FIGUEIREDO, A. \& LIMONGI, F. (1999), Executivo e Legislativo na nova ordem constitucional. Rio de Janeiro, FGV.

JUNQUEIRA, M. D. O. (2010), O nó tributário: 
porque não se aprova uma reforma tributária no Brasil. São Paulo, tese de doutorado, Departamento de Ciência Política da Universidade de São Paulo.

KREHBIEL, K. (1988), "Spatial models of Legislative choice. Legislative Studies Quarterly, 13 (3): 259-319.

LAMOUNIER, B. (1996), A democracia no limiar do século XXI. São Paulo, Fundação Konrad Adenauer.

LIMONGI, F. (2006), "A democracia no Brasil”. Novos Estudos Cebrap, 76: 17-41.

LOWI, T. J. (1964), "American business, public policy, case-studies, and political theory". World Politics, 16 (4): 677-715.

MAINWARING, S. (2001), Sistemas partidários em novas democracias: o caso do Brasil. Porto Alegre, Mercado Aberto.

MANCUSO, W. P. (2007), O lobby da indústria no Congresso Nacional: empresariado e politica no Brasil contemporâneo. São Paulo, Edusp/ Humanitas.

MCKELVEY, R. D. (1976), "Intransitivities in multidimensional voting models and some implications for agenda control". Journal of Economic Theory, 12 (3): 472-482.

(1979), "General conditions for global intransitivities in formal voting models". Econometrica, 47 (5): 1085-1112.

MELO, M. A. (2005), "O leviatã brasileiro e a esfinge argentina: os determinantes institucionais da política tributária”. Revista Brasileira de Ciências Sociais, 20 (58): 91-128.

NASCIMENTO, S. P. do. (2008), "Guerra fiscal: uma avaliação comparativa entre alguns estados participantes". Economia Aplicada, 12 (4): 677-706.

OLIVEIRA, L. G. de. (1999), "Federalismo e guerra fiscal". Pesquisa e Debate, 10 (16): 110-137.

ORDESHOOK, P. C. (1997), "The spatial analysis of elections and committees", in Dennis C. Mueller (ed.), Perspectives on public choice: a handbook, Cambridge, Cambridge University Press, pp. 247-270.

ORGANIZAÇÕES SOCIAIS. (2009), "Manifesto em defesa dos direitos sociais básicos sob ameaça na reforma tributária”. Brasília. Disponí- vel em http://conselho.saude.gov.br/webtributaria/doc/carta.pdf, consultado em 2 set. 2015.

PINTOS-PAYERAS, J. (2010), "Análise da progressividade da carga tributária sobre a população brasileira". Pesquisa e Planejamento Econômico, 40 (2): 153-186.

PRADO, S. (1999), "Guerra fiscal e políticas de desenvolvimento estadual no Brasil”. Economia e Sociedade, 13: 1-40, dez.

PRADO, S. \& CAVALCANTI, E. G. C. (2000), $A$ guerra fiscal no brasil. Brasília, Fundap/Fapesp/ Ipea.

REZENDE, F. (2009), Reforma tributária e federação. Rio de Janeiro, FGV.

SADEK, M. T. (2010), "Poder Judiciário: uma nova instituição". Cadernos Adenauer, XI (1): 13-21.

SHEPSLE, K. A. (1979), "Institutional arrangements and equilibrium in multidimensional voting models". American Journal of Political Science, 23 (1): 27-59.

(1986), "The positive theory of legislative institutions: an enrichment of social choice and spatial models". Public Choice, 50 (1-3): 135-178.

SILVA, S. J. da. (2007), Reforma da previdência em perspectiva comparada: Executivo, Legislativo e sindicatos na Argentina e no Brasil. São Paulo, Humanitas.

SILVEIRA, F. G. et al. (2013), "Fiscal equity: distributional impacts of taxation and social spending". Working Paper International Policy for Inclusive Growth, n. 115.

STEPAN, A. (1999), "Para uma nova análise comparativa do federalismo e da democracia: federações que restringem ou ampliam o poder do Demos". Dados, 42 (2): 197-251.

TSEBELIS, G. (1997), "Processo decisório em sistemas políticos: veto players no presidencialismo, parlamentarismo, multicameralismo e pluripartidarismo". Revista Brasileira de Ciências Sociais, 2: 89-117.

VARSANO, R. (1997), "A evolução do sistema tributário brasileiro ao longo do século: anotaçôes e reflexões para futuras reformas". Pesquisa e Planejamento Econômico, 27 (1): 1-40.

VIANNA, S. W.; SILVEIRA, F. G. \& TOMICH, F. 
A. (2000), "Carga tributária direta e indireta sobre as unidades familiares no Brasil: avaliação de sua incidência nas grandes regiões urbanas em 1996". Texto para discussão Ipea, vol. 757.

WILSON, J. Q. (1984), "Politics of regulation", in T. Ferguson e J. Rogers (eds.), The political economy: readings in the politics and economics of American public policy, Nova York, Routledge, pp. 81-103.

YOSHIDA, I. F. (2006), Governadores estaduais e partidos políticos na reforma administrativa do governo FHC: negociação e análise da votação. São Paulo, tese de mestrado, Departamento de Ciência Política da Universidade de São Paulo.

ZOCKUN, M. H. et al. (2007), "Simplificando o Brasil: propostas de reforma na relação econômica do governo com o setor privado". Texto para discussão Fipe, vol. 106. 


\section{O NÓ DA REFORMA TRIBUTÁRIA NO BRASIL (1995-2008)}

\section{Murilo de Oliveira Junqueira}

Palavras-chave: Federalismo; Reforma tributária; Reforma do Judiciário; Reforma administrativa; Sistema político.

Este trabalho analisa as razões do recorrente fracasso das reformas tributárias no Brasil. A análise mostrou que as explicaçôes correntes na literatura política (ingovernabilidade, veto federativo, oposição do empresariado e desinteresse do Executivo) não são suficientes para explicar tais fracassos. Introduz, pois, uma nova hipótese: a estratégia política da reforma. A ampla insatisfação com os tributos no Brasil induz o governo a propor reformas abrangentes, que alteram muitos aspectos da intrincada estrutura tributária, o que gera conflitos multidimensionais, ou seja, o aparecimento de diversas clivagens políticas simultâneas. Como comparação, foram analisadas as reforma do Judiciário, a reforma administrativa e alterações menores no sistema tributário. O resultado mostrou que as reformas tributárias tentavam impor custos concentrados a um maior número de atores, facilitando a formação de uma coalizão de veto.

\section{THE PUZZLE OF THE TAX REFORM IN BRAZIL (1995-2008)}

\section{LE NOEUD DE LA RÉFORME FISCALE AU BRÉSIL (1995-2008)}

\section{Murilo de Oliveira Junqueira}

Keywords: Federalism; Tax reform; Judicial reform; Administrative reform; Political system.

The paper analyses the reasons for the recurrent failure of tax reform in Brazil. The analysis show that the current explanations provided by the political literature (ingovernability, federal veto, opposition from business community, lack of political will of the government) are not enough to explain such failure. The issue of the political strategy for the reform is the hypothesis discussed in the paper. The widespread dissatisfaction with taxes in Brazil induces the government to propose comprehensive reforms altering many aspects of the intricate tax structure of the country. Such proposals have been generating multidimensional conflicts, i.e. many concurrent political divisions. With the purpose of providing elements for comparison, the judicial and the administrative reforms were analyzed, as well as were minor changes in the tax system. The results showed that the tax reforms imposed concentrated costs on a greater number of actors, favoring the formation of a veto coalition.

\section{Murilo de Oliveira Junqueira}

Mots-clés: Fédéralisme; Réforme fiscale; Réforme du judiciaire; Réforme administrative; Systéme politique.

Ce travail analyse les raisons de l'échec récurrent des réformes fiscales au Brésil. Il montre que les explications habituellement avancées dans la littérature politique (ingouvernabilité, veto fédératif, opposition de l'entrepreneuriat et désintérêt du pouvoir exécutif) ne sont pas suffisantes pour expliquer de tels échecs. D'où l'introduction d'une nouvelle hypothèse: la stratégie politique de la réforme. La grande insatisfaction par rapport aux impôts amène le gouvernement brésilien à proposer des réformes globales qui modifient plusieurs aspects de la structure fiscale inextricable, ce qui entraîne des conflits multidimensionnels, c'est-à-dire plusieurs clivages politiques spontanés. En guise de comparaison, l'étude s'est penchée sur la réforme du judiciaire, sur la réforme administrative et sur les altérations mineures du système fiscal. Les résultats indiquent que les réformes fiscales tentent de concentrer les coûts sur un plus grand nombre d'acteurs, facilitant ainsi la formation d'un veto coalisé. 